\title{
YIELD AND SUGAR CONTENT OF EUROPEAN MAIZE (ZEA MAYS L.) CULTIVARS GROWN IN POLAND
}

\author{
GĄSIOROWSKA, B. - PŁAZA, A. - RZĄŻEWSKA, E. * - WARANICA, M. \\ Agrotechnology Department, Faculty of Natural Sciences, Siedlce University of Natural \\ Sciences and Humanities, Siedlce, Poland \\ (e-mails: barbara.gasiorowska@uph.edu.pl; anna.plaza@uph.edu.pl; szur@uph.edu.pl) \\ *Corresponding author \\ e-mail: emilia.rzazewska@uph.edu.pl \\ (Received $4^{\text {th }}$ Jun 2019; accepted $2^{\text {nd }}$ Sep 2019)
}

\begin{abstract}
The work presents results of a research conducted in 2009-2011 to assess the yield and sugar content of selected maize (Zea mays L.) cultivars included in the Common Catalogue of Varieties of Agricultural Plant Species (CCA), harvested at various development stages, which affects the quality of animal feed produced, and select cultivars suitable for cultivation under the soil and climatic conditions of Poland. Two factors were examined in the study: A - the harvest date of maize green matter ( $\mathrm{I}$ - tasseling stage ( $75 \%$ of plants at this stage), II - milk maturity stage (after three weeks), III - wax maturity stage (after another three weeks)); B - cultivars with different earliness of maturity: Pyroxenia - very early, FAO 130, Codimi - early FAO 200, Moschus - early, FAO 220, Alombo - medium early, FAO 230, and Celive - medium early, FAO 245. Total protein yield, dry matter and starch content, soluble sugars and reducing sugars were determined in maize plants. The obtained study results demonstrated that the highest total protein yield was produced by the following maize cultivars: Codimi, Moschus, Alombo and Celive harvested at the wax maturity stage. The highest starch content was determined in the plants of cv. Pyroxenia, Codimi, Alombo and Celive also harvested at the wax maturity stage. Maize plants of all the examined cultivars harvested at the milk maturity stage and cv. Pyroxeni harvested at the tasseling stage had the highest soluble sugars and reducing sugars.
\end{abstract}

Keywords: FAO, harvest date, total protein yield, dry matter, starch

\section{Introduction}

As the cultivation area of maize and the crop's economic importance are increasing, there is also an increase in the demand for better cultivars - hybrids. Nowadays, breeding new maize cultivars makes use of heterosis or hybrid vigour which is displayed in the $F_{1}$ generation obtained as a result of crossing maternal and paternal inbred lines (Adamczyk, 2001; Sulewska et al., 2011). According to Jha et al. (1998) and Michalski et al. (2002), the role new cultivars play in modern agriculture is of great importance. In the cultivation of maize, breeding of new cultivars is developing dynamically, so it is advisable to study new cultivars recommended for cultivation in Poland, as well as from the CCA Community Catalog with neighboring countries. Thus, it is could prove beneficial to examine new cultivars originating from neighbouring countries and grown under the soil and climatic conditions of Poland. Both yielding and chemical composition of maize green feed are cultivar-related (Korniewicz et al., 2000; Ptaszyńska and Sulewska, 2008; Lynch et al., 2012). In their experiments, Filya (2004) and Komainda et al. (2018) observed that the greatest changes in organic matter chemical composition are associated with maize development stages. The more the harvest date is delayed, the higher increase in soluble sugars and starch content, and the lower the protein content of maize plants. Their contents are the highest when maize plants are at the milk maturity stage. The paucity of Polish literature on the subject 
provided an incentive to conduct this research. Its objective was to assess yielding and sugar content in maize plants of selected cultivars included in the Common Catalogue of Varieties of Agricultural Plant Species (CCA), harvested at various development stages which affect the quality of animal feed produced, and select cultivars suitable for cultivation under the soil and climatic conditions of Poland.

\section{Materials and methods}

Field studies were conducted in 2009-2011 on a private holding located in Kowiesy near Siedlce $\left(52^{\circ} 03^{\prime} 39^{\prime \prime} \mathrm{N}, 22^{\circ} 33^{\prime} 80^{\prime}\right.$ ' E). The field trial was set up on the soil classified as Albic Luvisol (Arenic) characterised by a slight acidity and average available phosphorus, potassium and magnesium contents. The soil's humus content was $1.28 \%$. The experiment was arranged as a split-plot design with three replicates. The area of one plot was $30 \mathrm{~m}^{2}$. The following two factors were investigated: A - maize green matter harvest date (I - tasseling stage ( $75 \%$ of plants at this stage), II - milk maturity stage (after three weeks), III - wax maturity stage (after another three weeks)); B - cultivars with different earliness of maturity (Pyroxenia - very early FAO 130, Codimi - early FAO 200, Moschus - early FAO 220, Alombo - medium early FAO 230, Celive - medium early FAO 245; Table 1). The number of plants per $1 \mathrm{~m}$ was 10 , and the sowing rate was established based on previous research by Sulewska (2001). Inter-row widths were $0.8 \mathrm{~m}$. Maize was grown in monoculture. In the autumn, cattle manure was applied at the rate of $30 \mathrm{t} \mathrm{ha}^{-1}$.

Table 1. Characteristics of studied cultivars

\begin{tabular}{c|c|c}
\hline Cultivar & Earliness of maturity & Number FAO \\
\hline Pyroxenia & Very early & 130 \\
Codimi & Early & 200 \\
Moschus & Early & 220 \\
Alombo & Medium early & 230 \\
Celive & Medium early & 245 \\
\hline
\end{tabular}

In spring, phosphorus and potassium fertilisers were applied at rates matching soil contents of available elements, that is $60 \mathrm{~kg} \mathrm{P} \mathrm{ha}^{-1}$ and $90 \mathrm{~kg} \mathrm{~K} \mathrm{ha}^{-1}$. Nitrogen fertiliser was applied pre-plant at the rate of $92 \mathrm{~kg} \mathrm{~N} \mathrm{ha}^{-1}$ in the spring and followed by maize, the nitrogen rate being increased due to an application of Polifoska 6. Seeds of the examined cultivars were planted in late April. Cv. Pyroxenia (bred by Trnava s.r.o. Slovakia, three-way cross (Tc)) is a hybrid characterised by extreme earliness, a high share of cobs in the yield structure, resistance to increased stand density and rapid increase in cob dry matter. Cv. Codimi (bred by Codimes, France, Tc) is an early maturing variety with a classical stay-green trait, rapid initial growth and a high share of grain dry matter in silage. Its plants are of medium height developing an abundance of wide leaves. Cv. Moschus (bred by Freiherr von Moreau Saatzucht GmbH, Germany, modified three-way cross (MTc)) is an early maturing multiple-use variety displaying the stay-green trait. It produces high yields of grain which easily releases water. Cv. Alombo (bred by Freiherr von Moreau Saatzucht GmbH, Germany, single cross (Sc)) is a multiple-use variety suitable for both grain and silage production even under poorer soil conditions. It has a high yield-production potential and good healthiness. Cv. Celive 
(bred by Cezea a.s., Czech Republic, Sc) is an early maturing hybrid suitable for grain production, cold-tolerant, producing high grain yields, which is indicative of high quality of silage produced from its green matter. The green matter of maize crop was harvested at three dates as set in the methodology. The plant matter was sampled to determine dry matter content, total protein content, starch content, soluble sugars and reducing sugars by means of near infrared spectroscopy (NIRS) using the spectrometer NIR Flex N-500. The analyses were performed at the certified laboratory of the Institute of Technology and Life Sciences in Falenty.

The results of the research were statistically analysed; ANOVA following the linear model for a two factor split-plot design was performed for each characteristic examined, and separation of means was obtained by means of Tukey test at the significance level of 0.05 . All the calculations were performed in STATISTICA ${ }^{\circledR}$, version 12.0 and MS Excel.

The studies were carried out on lessive soil. Maize was grown in monoculture. Nitrogen at a dose of $92 \mathrm{~N} \mathrm{~kg} \mathrm{ha}^{-1}$ was applied in spring before sowing maize in the form of urea for the tilling set, the additional nitrogen dose was increased by the use of mineral fertilizer in the form of Polifoska 6. Phosphorus at a dose of $60 \mathrm{P} \mathrm{kg} \mathrm{ha}^{-1}$ and potassium at a dose of $90 \mathrm{~K} \mathrm{~kg} \mathrm{ha}^{-1}$ was applied in the form of multi-component mineral fertilizer-Polifoska 6 in spring.

Weather conditions in the 2009 growing season were moderately favorable for the proper vegetation of corn plants. During the growing season of 2010, weather conditions favored the growth, development and yielding of maize. The vegetation season of 2011 was varied in terms of both rainfall and temperature.

\section{Results}

\section{The total protein yield of maize plants}

Total protein yield of maize plants varied significantly due to the impact of the experimental factors and their interaction (Table 2).

Table 2. Total protein yield of maize plants (means across 2009-2011), $\mathrm{kg} \mathrm{ha}^{-1}$

\begin{tabular}{|c|c|c|c|c|}
\hline \multirow{2}{*}{ Cultivars (B) } & \multicolumn{3}{|c|}{ Harvest date (A) } & \multirow{2}{*}{ Means } \\
\hline & $\mathbf{I}$ & II & III & \\
\hline Pyroxenia & $656 b$ & $1152 \mathrm{a}$ & $1419 b$ & 1076B \\
\hline Codimi & $773 a$ & $1068 b$ & $1598 \mathrm{a}$ & $1146 \mathrm{~A}$ \\
\hline Moschus & $690 \mathrm{a}$ & $1221 \mathrm{a}$ & $1624 a$ & $1179 \mathrm{~A}$ \\
\hline Alombo & $878 \mathrm{a}$ & $1336 a$ & $1768 \mathrm{a}$ & $1327 \mathrm{~A}$ \\
\hline Celive & $794 a$ & $1189 a$ & $1755 \mathrm{a}$ & $1246 \mathrm{~A}$ \\
\hline Średnie & $758 \mathrm{C}$ & 1193B & $1633 \mathrm{~A}$ & - \\
\hline ANOVA & \multicolumn{2}{|c|}{ P-value } & \multicolumn{2}{|c|}{ LSD $_{0.05}$} \\
\hline Harvest date (A) & \multicolumn{2}{|c|}{$<0.001$} & \multicolumn{2}{|c|}{223} \\
\hline Cultivars (B) & \multicolumn{2}{|c|}{$<0.001$} & \multicolumn{2}{|c|}{223} \\
\hline Interaction (AxB) & \multicolumn{2}{|c|}{$<0.001$} & \multicolumn{2}{|c|}{230} \\
\hline
\end{tabular}

Values in columns followed by the same small letter and values in rows followed by the same capital letter do not differ significantly at $\mathrm{P}<0.05$ 
The highest total protein yield was produced by maize plants harvested at the wax maturity stage, it being significantly lower at the milk maturity stage and the lowest at the tasseling stage. Cultivars had a significant influence on total protein yield. The yield produced by cv. Codimi, Moschus, Alombo and Celive was the highest and differed insignificantly between the cultivars, it being significantly lower for cv. Pyroxenia only. An interaction between the experimental factors was determined which indicated that the highest total protein content was produced by cv. Codimi, Moschus, Alombo and Celive harvested at the wax maturity stage, it being the lowest for all the examined cultivars harvested at the tasseling stage.

\section{The dry matter content in maize plants}

Statistical analysis revealed a significant influence of the experimental factors and their interaction on dry matter content in maize plants (Table 3).

Table 3. Dry matter content in maize plants (means across 2009-2011), $\mathrm{g} \mathrm{kg}^{-1}$

\begin{tabular}{|c|c|c|c|c|}
\hline \multirow{2}{*}{ Cultivars (B) } & \multicolumn{3}{|c|}{ Harvest date (A) } & \multirow{2}{*}{ Means } \\
\hline & I & II & III & \\
\hline Pyroxenia & $142.1 \mathrm{a}$ & $243.4 \mathrm{a}$ & $361.4 \mathrm{a}$ & $249.0 \mathrm{~A}$ \\
\hline Codimi & $137.2 \mathrm{a}$ & $247.4 \mathrm{a}$ & $356.8 \mathrm{a}$ & $247.2 \mathrm{~A}$ \\
\hline Moschus & $131.3 \mathrm{a}$ & $238.9 \mathrm{a}$ & $330.3 b$ & $233.5 \mathrm{~A}$ \\
\hline Alombo & $134.1 \mathrm{a}$ & $216.1 \mathrm{~b}$ & $341.6 \mathrm{a}$ & $230.6 \mathrm{~A}$ \\
\hline Celive & $135.8 \mathrm{a}$ & $218.2 b$ & $325.0 \mathrm{~b}$ & 226.3B \\
\hline Średnie & $136.1 \mathrm{C}$ & $232.8 \mathrm{~B}$ & $343.0 \mathrm{~A}$ & - \\
\hline ANOVA & \multicolumn{2}{|c|}{ P-value } & \multicolumn{2}{|c|}{ LSD $_{0.05}$} \\
\hline Harvest date (A) & \multicolumn{2}{|c|}{$<0.001$} & \multicolumn{2}{|c|}{20.1} \\
\hline Cultivars (B) & \multicolumn{2}{|c|}{$<0.001$} & \multicolumn{2}{|c|}{20.2} \\
\hline Interaction $(\mathrm{AxB})$ & \multicolumn{2}{|c|}{$<0.001$} & \multicolumn{2}{|c|}{23.0} \\
\hline
\end{tabular}

Values in columns followed by the same small letter and values in rows followed by the same capital letter do not differ significantly at $\mathrm{P}<0.05$

The highest dry matter content was recorded for maize plants harvested at the wax maturity stage, it being significantly lower at the milk maturity stage and the lowest at the tasseling stage. Cultivars significantly affected dry matter content in maize plants, as well. The highest dry matter content was determined in maize cv. Pyroxenia, Codimi, Moschus and Alombo, it being the lowest in the green matter of maize cv. Celive. An interaction between the experimental factors was confirmed indicating that the highest dry matter content was found in maize plants of cv. Pyroxenia, Codimi, Moschus and Alombo harvested at the wax maturity stage, it being the lowest for all the cultivars harvested at the tasseling stage.

\section{The starch content in maize plants}

Starch content in maize plants was significantly affected by harvest date, cultivars and their interaction (Table 4). 
Table 4. Starch content in maize plants (means across 2009-2011), $\mathrm{g} \mathrm{kg}^{-1}$ d.m.

\begin{tabular}{|c|c|c|c|c|}
\hline \multirow{2}{*}{ Cultivars (B) } & \multicolumn{3}{|c|}{ Harvest date (A) } & \multirow{2}{*}{ Means } \\
\hline & I & II & III & \\
\hline Pyroxenia & $32.0 \mathrm{a}$ & $280.2 \mathrm{a}$ & $401.5 \mathrm{a}$ & $237.8 \mathrm{~A}$ \\
\hline Codimi & $67.0 \mathrm{a}$ & $198.8 \mathrm{~b}$ & $394.0 \mathrm{a}$ & $219.9 \mathrm{~A}$ \\
\hline Moschus & $50.7 \mathrm{a}$ & $189.8 \mathrm{~b}$ & $348.7 b$ & 196.4B \\
\hline Alombo & $40.6 \mathrm{a}$ & $159.0 \mathrm{c}$ & $356.1 \mathrm{a}$ & 185.2B \\
\hline Celive & $51.7 \mathrm{a}$ & $176.5 b$ & $359.9 \mathrm{a}$ & 196.0B \\
\hline Średnie & $48.4 \mathrm{C}$ & $200.8 \mathrm{~B}$ & $372.0 \mathrm{~A}$ & - \\
\hline$A N O V A$ & \multicolumn{2}{|c|}{ P-value } & \multicolumn{2}{|c|}{ LSD $_{0.05}$} \\
\hline Harvest date (A) & \multicolumn{2}{|c|}{$<0.001$} & \multicolumn{2}{|c|}{26.2} \\
\hline Cultivars (B) & \multicolumn{2}{|c|}{$<0.001$} & \multicolumn{2}{|c|}{32.3} \\
\hline Interaction $(\mathrm{AxB})$ & \multicolumn{2}{|c|}{$<0.001$} & \multicolumn{2}{|c|}{48.0} \\
\hline
\end{tabular}

Values in columns followed by the same small letter and values in rows followed by the same capital letter do not differ significantly at $\mathrm{P}<0.05$

The highest starch content was recorded in maize plants harvested at the wax maturity stage, it being significantly lower at the milk maturity stage and the lowest at the tasseling stage. Cultivars had a significant influence on starch content in maize plants. The highest starch content was determined in the maize plants of cv. Pyroxenia and Codimi, it being significantly lower in cv. Moschus, Alombo and Celive. An interaction between the experimental factors was confirmed: the highest starch content was recorded in maize plants of cv. Pyroxenia, Codimi, Alombo and Celive harvested at the wax maturity stage, and the lowest for all the examined cultivars harvested at the tasseling stage.

\section{The soluble sugars in maize plants and reducing sugars in maize plants}

Statistical analysis demonstrated a significant effect of harvest date and an interaction between harvest dates and cultivars on soluble sugars and reducing sugars in maize plants (Tables 5 and 6 ).

Table 5. Soluble sugars in maize plants (means across 2009-2011), $\mathrm{g} \mathrm{kg}^{-1} \mathrm{~d} . \mathrm{m}$.

\begin{tabular}{|c|c|c|c|c|}
\hline \multirow{2}{*}{ Cultivars (B) } & \multicolumn{3}{|c|}{ Harvest date (A) } & \multirow{2}{*}{ Means } \\
\hline & $\mathbf{I}$ & II & III & \\
\hline Pyroxenia & $80.7 \mathrm{a}$ & $72.1 \mathrm{~b}$ & $33.8 \mathrm{~b}$ & 62.2 \\
\hline Codimi & $53.6 \mathrm{~b}$ & $78.5 \mathrm{~b}$ & $39.0 \mathrm{~b}$ & 57.0 \\
\hline Moschus & $53.6 \mathrm{~b}$ & $81.3 \mathrm{a}$ & $50.0 \mathrm{a}$ & 61.6 \\
\hline Alombo & $50.6 \mathrm{~b}$ & $85.6 \mathrm{a}$ & $55.4 \mathrm{a}$ & 63.9 \\
\hline Celive & $56.3 \mathrm{~b}$ & $82.4 \mathrm{a}$ & $48.5 \mathrm{a}$ & 62.4 \\
\hline Średnie & $58.9 \mathrm{~B}$ & $80.0 \mathrm{~A}$ & $45.3 \mathrm{C}$ & - \\
\hline ANOVA & \multicolumn{2}{|c|}{ P-value } & \multicolumn{2}{|c|}{ LSD $_{0.05}$} \\
\hline Harvest date (A) & \multicolumn{2}{|c|}{$<0.001$} & \multicolumn{2}{|c|}{9.7} \\
\hline Cultivars (B) & \multicolumn{2}{|c|}{-} & \multicolumn{2}{|c|}{ r.n. } \\
\hline Interaction $(\mathrm{AxB})$ & \multicolumn{2}{|c|}{$<0.001$} & \multicolumn{2}{|c|}{19.4} \\
\hline
\end{tabular}

Values in columns followed by the same small letter and values in rows followed by the same capital letter do not differ significantly at $\mathrm{P}<0.05$ 
Table 6. Reducing sugars in maize plants (means across 2009-2011), $\mathrm{g} \mathrm{kg}^{-1}$ d.m.

\begin{tabular}{|c|c|c|c|c|}
\hline \multirow{2}{*}{ Cultivars (B) } & \multicolumn{3}{|c|}{ Harvest date (A) } & \multirow{2}{*}{ Means } \\
\hline & I & II & III & \\
\hline Pyroxenia & $51.3 \mathrm{a}$ & $51.6 \mathrm{a}$ & $28.7 \mathrm{~b}$ & 43.8 \\
\hline Codimi & $43.6 \mathrm{a}$ & $56.2 \mathrm{a}$ & $32.1 \mathrm{~b}$ & 44.0 \\
\hline Moschus & $42.5 b$ & $54.0 \mathrm{a}$ & $38.6 \mathrm{a}$ & 45.1 \\
\hline Alombo & $42.1 \mathrm{~b}$ & $56.4 \mathrm{a}$ & $39.1 \mathrm{a}$ & 45.9 \\
\hline Celive & $44.7 \mathrm{a}$ & $56.7 \mathrm{a}$ & $41.5 \mathrm{a}$ & 47.6 \\
\hline Średnie & $44.8 \mathrm{~B}$ & $55.0 \mathrm{~A}$ & $36.0 \mathrm{C}$ & - \\
\hline ANOVA & \multicolumn{2}{|c|}{ P-value } & \multicolumn{2}{|c|}{$\operatorname{LSD}_{0.05}$} \\
\hline Harvest date (A) & \multicolumn{2}{|c|}{$<0.001$} & \multicolumn{2}{|c|}{3.0} \\
\hline Cultivars (B) & \multicolumn{2}{|c|}{ - } & \multicolumn{2}{|c|}{ r.n. } \\
\hline Interaction (AxB) & \multicolumn{2}{|c|}{$<0.001$} & \multicolumn{2}{|c|}{7.8} \\
\hline
\end{tabular}

Values in columns followed by the same small letter and values in rows followed by the same capital letter do not differ significantly at $\mathrm{P}<0.05$

The largest amounts of soluble sugars and reducing sugars were found in maize plants harvested at the milk maturity stage, them being significantly lower at the tasseling stage and the lowest at the wax maturity stage. An interaction between the experimental factors was confirmed which indicated that the highest amounts of soluble and reducing sugars were characteristic of all the experimental maize cultivars harvested at the milk maturity stage and cv. Pyroxenia plants harvested at the tasseling stage. The lowest soluble sugar contents were determined for maize plants of cv. Pyroxenia, Codimi, Moschus and Celive harvested at the wax maturity stage whereas reducing sugars were the lowest for cv. Pyroxenia and Codimi harvested at the same maturity stage.

\section{Discussion}

Maize is a crop plant which provides bulky feed produced in ploughed fields and characterised by many beneficial characteristics, Animal feed produced from the whole plants has a high energy value but a low protein content (Brzóska, 2001; Schittenhelm, 2008). In the present study, the highest total protein yield was obtained from maize plants harvested at the wax maturity stage, which was due to the highest dry matter yield. Similar findings were reported by Stejskalove et al. (2013), Magalhäes et al. (2015) and Nowab et al. (2017) who demonstrated that a delay in the harvest of maize plants contributed to an increase in total protein yield. In the study discussed here, cultivars affected the total protein yield, too. Cv. Codimi, Moschus, Alombo and Celive were superlative in terms of total protein yield. Similar relationships were observed by Verbic et al. (1997). In the present work, cv. Pyroxenia produced the lowest total protein yield because it is flint type which has the shortest growing season.

Similarly to Magalhäes et al. (2015) and Podkówka et al. (2015), in the experiment presented here a delay in maize harvest was followed by an increase in dry matter. Cultivars had a significant effect on dry matter content in maize plants. The highest concentration of this component was recorded in maize plants of cv. Pyroxenia, Codimi, Moschus and Alombo. Celive was the cultivar with the lowest dry matter content. Also 
Magalhäes et al. (2015) found the lowest dry matter content in maize plants of cv. Celive characterised by the longest growing season.

In the present work, the highest starch content was recorded in maize plants harvested at the wax maturity stage. The results are similar to those reported by other authors (Tolera et al., 1998; Yuxiang et al. (2007). When harvest was delayed, there was observed an increase in starch content in the dry matter of green feed, which is closely correlated with maize maturity stage. In the experiment discussed here, significant differences were found between starch content in the dry matter of maize plants representing the experimental cultivars. The concentration of starch was higher in the dry matter of two early maize cultivars, that is Pyroxenia and Codimi. Also Tolera et al. (1999), Strzetelski et al. (2001) and Szempliński et al. (2009) mentioned that starch content was higher in the dry matter of earlier maturing maize cultivars.

In the current work, there was confirmed a significant effect of maize harvest date on soluble sugars and reducing sugars in the plants. The highest concentration of the sugars in the dry matter of maize green matter was recorded when plants had been harvested at the milk maturity stage. A delay in harvest until plants reached the wax maturity stage contributed to a decline in soluble sugars and reducing sugars, and an increase in starch content. The above relationship was also reported by Lynch et al. (2012) and Magalhäes et al. (2015). Maize harvest at the wax maturity stage is associated with the highest starch content, which contributes to the production of the best quality silage. Of the examined cultivars, early representatives, that is Pyroxenia adn Codimi, had the most beneficial chemical composition of green matter.

A new approach to the problem to examine cultivars from neighboring international countries in Poland's soil and climate conditions. New cultivars such as Pyroxenia and Codimi are available for cultivation in Poland and provide the best feed.

\section{Conclusions}

(1) The highest total protein content was produced by maize cv. Codimi, Moschus, Alombo and Celive harvested at the wax maturity stage. Maize cv. Pyroxenia, Codimi, Moschus and Alombo harvested at the wax maturity stage had the highest dry matter content.

(2) The highest starch content was recorded in maize cv. Pyroxenia, Codimi, Alombo and Celive harvested at the wax maturity stage.

(3) All the examined maize cultivars harvested at the milk maturity stage, and cv. Pyroxenia harvested at the tasseling stage produced the highest amounts of soluble sugars and reducing sugars.

(4) It is necessary to continue research on the cultivation of new cultivars from the CCA community catalogue in Polish soil and climate conditions.

\section{REFERENCES}

[1] Adamczyk, J. (2001): The importance of selecting varieties in the cultivation of maize for grain and silage. - Biul. Inf. IŻ - R. XXXIX(1): 29-35 (in Polish).

[2] Brzóska, F. (2001): Nutritional value of fodder from corn. - Biul. Inf. IŻ, R. XXXIX(1): $37-48$ (in Polish).

[3] Filya, I. (2004): Nutritive value and aerobic stability of whole crop maize silage harvested at four stages of maturity. - Anim. Feed Sci. Tech. 116: 141-150. 
[4] Jha, P. B., Ghosh, J., Nirala, R. B. P. (1998): Genetic variability and character association in fodder maize. - J. Res. Birsa Agric. Univ. 10(2): 139-143.

[5] Komainda, M., Taube, F., Klub, C., Antje, H. (2018): The effects of maize (Zea Mays L.) hybrid and harvest date on above-and belowground biomass dynamics, forage yield and quality - a trade-off for carbon inputs? - Eur. Jour. Agron. 92: 51-62.

[6] Korniewicz, A., Kosmala, I., Czarnik-Matusewicz, H., Paleczek, B. (2000): The contents of basic nutrients in the grain of different maize hybrids. - Rocz. Nauk Zoot. 27(1): 289303 (in Polish).

[7] Lynch, J. P., O'Kiely, P., Doyle, E. M. (2012): Yield, quality and ensilage characteristics of whole-crop maize and of the cob and stover components: harvest date and hybrid effect. - Grass Forage Sci. 67(4): 472-487.

[8] Magalhäes, A., Rolim, M., Duarte, A., Pedrosa, E., Silva, E. (2015): Chemical attributes of soil and dry mass accumulation of maize fertilized with cassava wastewater. - Engen. Agric. 35(3): 458-469.

[9] Michalski, T., Kruczyńska, H., Kowalik, I. (2002): Yields and quality of ensilaging maize depending on the cultivar and mowing height at harvested. - Acta Sci. Pol. Agric. 1(2): 83-92.

[10] Nawab, A., Anjum, M. M. (2017): Effect of different nitrogen rates on growth, yield and quality of maize. - Mid. East Jour. Agric. Res. 6(1): 107-112.

[11] Podkówka, L., Podkówka, Z., Piwczyński, D., Buko, M. (2015): Effect of cultivar earliness on chemical composition and digestibility of maize grain. - Rocz. Nauk Zoot. 42(2): 155-169 (in Polish).

[12] Ptaszyńska, G., Sulewska, H. (2008): Yield variation of maize hybrids with different growing period in climatic conditions of Central Wielkopolska region. - Acta Sci. Pol. Agric. 7(3): 93-103 (in Polish).

[13] Schittenhelm, S. (2008): Chemical composition and methane field of maize hybrids with contrasting maturity. - Eur. Jour. Agron. 29(2-3): 72-78.

[14] Sulewska, H. (2001): Yielding and nutritive value of maize harvested on green mass depending on some agrotechnical factors. - Rocz. AR Poznań. Rozp. nauk. 315 (in Polish).

[15] Sulewska, H., Adamczyk, J., Rejek, D. (2011): Evaluation of the yield of new hybrids of fodder maize (Zea Mays L.) of Smolice breeding. - Nauka Przy. Tech. 5(1): 1-11.

[16] Stejskalova, M., Hejcmanova, P., Hejcman, M. (2013): Forage value of leaf fodder main European broad-leaved woody species. The role of grassland in a green future. - Grassl. Sci. Europe 18: 85-87.

[17] Strzetelski, A., Jurkiewicz, A., Strzetelski, J. (2001): Maize silage in cattle feed. - Biul. Inf. Inst. Zoot. 39(1): 49-62 (in Polish).

[18] Szempliński, W., Bogucka, B., Wróbel, E. (2009): Suitability of early and mid-early maize hybrids grown in the province of Warmia and Mazury for silage production. - Acta Sci. Pol. Agric. 8(1): 57-68 (in Polish).

[19] Tolera, A., Sundstolb, F., Saidc, A. (1998): The effect of stage of maturity on yield and quality of maize grain and stover. - Anim. Feed Sci. Tech. 75(2): 157-168.

[20] Tolera, A., Berg, T., Sundstolb, F. (1999): The effect of variety on maize grain and crop residue yield and nutritive value of the stover. - Anim. Feed Sci. Technol. 79(3): 165177.

[21] Verbic, J., Babnik, D., Gregorcic, A., Kmetic, M. (1997): Morphology and chemical composition of two maize hybrids and their influence on silage quality. - Zb. Biotech. Fak. Univ. v Ljubljani Kmetijstvo 70: 175-185.

[22] Yuxiang, Ch., Jing, Ch., Daowei, Z. (2007): Effect of harvest date on shearing force of maize stems. - Liv. Sci. 111(1): 33-44. 